\title{
Dietary niche overlap in a nearshore elasmobranch mesopredator community
}

\author{
Jeremy J. Vaudo*, Michael R. Heithaus \\ Marine Science Program, Department of Biological Sciences, Florida International University, 3000 NE 151 Street, \\ North Miami, Florida 33181, USA
}

\begin{abstract}
Understanding mesopredator trophic interactions is crucial to understanding the dynamics of food webs because mesopredators provide the link between apex predators and lower trophic levels. Using stable isotopic analysis and stomach content analysis, we examined dietary niche overlap within a diverse elasmobranch mesopredator community in Shark Bay, Western Australia. Isotopic values $\left(\delta^{13} \mathrm{C}\right.$ and $\left.\delta^{15} \mathrm{~N}\right)$ were consistent with most species being highly dependent on a seagrass-based food web. Differences were observed between the mean isotopic values of species, but there was a great deal of overlap in the isotopic niche space used by the community when examined at the level of individuals. Stomach contents also suggest dietary overlap among the diets of Himantura spp. and Glaucostegus typus, which contained many of the same prey species, primarily crustaceans typically associated with seagrass habitats, although in different proportions. Diet data also suggest that, despite having isotopic values similar to other species, Pastinachus atrus appears to feed on sandflat-associated species. In this community, variation within the groups examined, possibly due to individual specialization, appears to result in high resource overlap and may be a key component allowing for high diversity in this system and is perhaps crucial to understanding the role of mesopredators in community trophic dynamics.
\end{abstract}

KEY WORDS: Stable isotope $\cdot$ Resource partitioning $\cdot$ Individual specialization $\cdot$ Stingray $\cdot$ Batoid Elasmobranch $\cdot$ Shark

Resale or republication not permitted without written consent of the publisher

\section{INTRODUCTION}

In recent years, the loss of apex predators has received a great deal of attention because of the potential these predators have to influence systems through top-down control (Pace et al. 1999, Heithaus et al. 2008). In fact, many ecosystems have experienced fundamental changes in structure and function because of apex predator loss (e.g. Terborgh et al. 2001, Ripple \& Beschta 2006). These changes are typically mediated by mesopredators, predators of intermediate trophic levels, which provide a crucial link between upper and lower trophic levels (Ritchie \& Johnson 2009). Therefore, given the role mesopredators likely play in determining structure and function of ecosystems, an understanding of the dynamics of mesopredator interactions is crucial to elucidating the potential effects of predation in systems.
Despite the importance of mesopredators in other ecosystems, elasmobranch mesopredators (i.e. small sharks and batoids) have often been neglected because focus has been placed on elasmobranch top predators (i.e. large sharks) (Heithaus et al. 2010). Batoids, in particular, have received relatively little attention in coastal communities, although they may influence community structure through predation and bioturbation (VanBlaricom 1982, Thrush et al. 1994, Peterson et al. 2001). For example, cownose ray foraging can result in widespread loss of shellfish and has been implicated as a factor in the collapse of a commercially important scallop fishery (Peterson et al. 2001, Myers et al. 2007). The trophic relationships of batoids may, therefore, be important in the systems they inhabit.

Shark Bay, Western Australia, supports a diverse community of elasmobranch mesopredators, especially batoids (White \& Potter 2004, Vaudo \& Heithaus 2009). 
Interestingly, many of the batoid species in Shark Bay have similar patterns of seasonal abundance and microhabitat use (Vaudo \& Heithaus 2009) and large numbers of batoid foraging pits pocket the areas of high batoid use (J. J. Vaudo unpubl. data). However, previous studies of the sandflat community of Shark Bay have revealed a depauperate invertebrate fauna (Wells et al. 1985, Black et al. 1990). The scarcity of potential prey in an area of high batoid density in which batoids are clearly foraging suggests that batoids may be partitioning available food resources. To date, there have been few studies examining resource partitioning in batoids (but see Platell et al. 1998, Bizzarro et al. 2007, Marshall et al. 2008). Such studies are necessary to assess the potential ecological impacts of individual species as well as batoid communities.

Traditionally, studies of dietary resource partitioning have relied on stomach content analysis; however, such analysis is not without its limitations. Animals often have empty stomachs and collected stomach contents represent only a snapshot of what an animal has eaten recently. This snapshot of the diet may also be skewed due to differences in the digestibility of prey; hard to digest prey may remain in the stomach for longer periods of time (Hyslop 1980). Stable isotopic analysis $\left(\delta^{13} \mathrm{C}\right.$ and $\left.\delta^{15} \mathrm{~N}\right)$, although providing lower taxonomic resolution, has several benefits over stomach content analysis, such as reflecting the assimilated material within the diet as opposed to ingested material and representing the longterm foraging of an individual (Peterson \& Fry 1987). As a result of these advantages and the ease of tissue collection, stable isotopic analysis has become an increasingly popular tool in studies of animal ecology. The goal of the present study was to examine the trophic niches of the members of the Shark Bay nearshore elasmobranch community, with an emphasis on batoids, and to investigate the possibility of dietary resource partitioning using these 2 complementary methods.

\section{MATERIALS AND METHODS}

Study site and sample collection. Shark Bay, Western Australia $\left(25^{\circ} 45^{\prime} \mathrm{S}, 113^{\circ} 44^{\prime} \mathrm{E}\right)$, located approximately $800 \mathrm{~km}$ north of Perth, is a large (ca. $13000 \mathrm{~km}^{2}$ ) semi-enclosed bay on the central west coast of Australia and contains some of the world's most extensive seagrass shoals (Walker 1989). Adjacent to the shore are expansive shallow sandflats with fringing shallow seagrass beds $(<4 \mathrm{~m})$.

Elasmobranchs are abundant in the shallow sandflat habitats and adjacent seagrass beds of Shark Bay during the warm season (September to May), although most species are also observed in the cold season (June to August), indicating that populations are probably residential (Vaudo \& Heithaus 2009). Fishing effort was focused on these nearshore habitats within $12 \mathrm{~km}$ of the Monkey Mia Dolphin Resort. We captured elasmobranchs between September 2005 and February 2009 using a combination of longlining (for brownbanded bamboo sharks Chilosyllium punctatum and giant shovelnose rays Glaucostegus typus) and netting techniques as detailed in Vaudo \& Heithaus (2009). All but 14 of 234 stable isotope samples (see below) and 3 of 154 gastric lavage attempts (see below) were from the warm season. For analyses, maskrays Neotrygon spp. (N. leylandi, N. kuhlii, and Neotrygon cf. ningalooensis) were grouped because of the limited number of animals captured. Blackspotted whipray Himantura astra and brown whipray $H$. toshi were also grouped for all analyses because they have often been confused in the literature (Last et al. 2008). Photographs of captured individuals confirmed that both species were present (W. White pers. comm.). All individuals were measured (total length [TL] or disc width [DW]), sexed, and a fin clip was taken from the trailing edge of the pelvic fin (trailing edge of dorsal fin of nervous sharks Carcharhinus cautus, C. punctatum, G. typus and smoothnose wedgefish Rhynchobatus laevis) for stable isotope analysis. As part of other stable isotopic studies a variety of primary producers (algae, including epiphytes, and seagrasses) were collected from the study site between March 2007 and July 2008 and used to determine the carbon source for these elasmobranchs. Primary producer samples (algae: warm season $\mathrm{n}=29$, cold season $n=29$; seagrass: warm season $n=62$, cold season $n=19$ ) were collected by hand and scraped clean of any epiphytes prior to processing. Filter feeding bivalves (i.e. mussels, pen shells, oysters and scallops; $\mathrm{n}=45$ ) were collected to represent the phytoplankton resource pool. All samples were frozen until processing.

When possible, we collected stomach contents by gastric lavage. During gastric lavage, an individual was inverted over a collection bin and a $2 \mathrm{~cm}$ diameter plastic tube was inserted into its stomach via the mouth. The free end of the plastic tubing was connected to a $38001 \mathrm{~h}^{-1}$ bilge pump, which was lowered over the gunwale into the water and activated. As the stomach filled with water, the tubing was gently moved around the stomach to facilitate flushing. When it appeared that no further contents would be collected, the tubing was removed from the individual's stomach. Stomach contents were recovered from the collection bin and frozen until processing. The large size range $(<1$ to $\sim 50 \mathrm{~cm}$ long) of items collected via gastric lavage suggests that this technique was adequate for sampling the diets of these individuals.

Stable isotope analysis. Prior to processing, we thawed and then washed samples in distilled water. 
The samples were then dried in a dehydrator for at least $48 \mathrm{~h}$ and then ground into a fine powder. The ground samples were then stored in a desiccator until analysis. Samples were analyzed for $\delta^{13} \mathrm{C}$ and $\delta^{15} \mathrm{~N}$ at the Yale Earth System Center for Stable Isotopic Studies. Homogenized trout standards analyzed at the same time as our samples had standard deviations ranging from 0.10 to $0.19 \%$ for $\delta^{13} \mathrm{C}$ and 0.02 to $0.08 \%$ for $\delta^{15} \mathrm{~N}$. As elasmobranch samples had low $\mathrm{C}: \mathrm{N}$ ratios $(2.59 \pm 0.13$, mean $\pm \mathrm{SD})$ and previous studies have found that elasmobranch body tissue has low lipid content (Devadoss 1984, Hussey et al. 2010), we did not correct $\delta^{13} \mathrm{C}$ values for the effects of lipids.

To investigate the relationship of size and the observed isotopic values of elasmobranchs, we used linear regression. For some species, the relationship between size and isotopic values appeared nonlinear. We split these species into size classes based on apparent breakpoints in the plotted data and treated size classes separately for all further analyses.

We plotted the individuals for each elasmobranch species or size class in $\delta^{13} \mathrm{C}-\delta^{15} \mathrm{~N}$ space ('isotopic niche space') and calculated the quantitative metrics suggested by Layman et al. (2007a). The total area (TA) occupied by each species is a proxy for the isotopic trophic diversity within that species and was calculated as the area of the convex hull that encompasses all individuals. The mean distance to the centroid (CD) represents the average degree of trophic diversity within the species and was calculated by determining the distances of each individual from the bivariate mean of all individuals. The mean nearest neighbor distance (NND) and standard deviation of nearest neighbor distances (SDNND) represent the density and evenness of individual packing within the isotopic niche space, respectively, and were calculated using the distances between each individual and all other individuals. We also calculated the mean distance of individuals to all other individuals (ND) and the standard deviation of all neighbor distances (SDND) as another measure of individual packing. These additional metrics were calculated because if individuals are aggregated in several clusters, NND and SDNND will not represent the clustering, resulting in inaccurate estimates of evenness (Quevedo et al. 2009). We calculated all distances and areas for these analyses using the Animal Movement Analyst Extension (AMAE) (Hooge \& Eichenlaub 2000) for ArcView GIS 3.2a.

This approach allowed for interspecific comparisons and assessment of overlap in isotopic niche space. To assess whether we had adequately sampled the intraspecific variability and therefore the full isotopic niche space used by a species, we used AMAE (Hooge $\&$ Eichenlaub 2000) to conduct bootstrap analyses $(\mathrm{n}=$
200) examining the mean TA across varying sample sizes. If the curves from the resulting sample size versus TA graphs reach an asymptote, the number of individuals sampled is considered sufficient for describing the isotopic niche space used. To determine if a curve reached an asymptote, we used the method devised by Bizzarro et al. (2007). We performed a linear regression on the final 4 endpoints of the curve to determine if the slope was significantly different from zero. If the slope did not differ from zero, we concluded that the curve had reached an asymptote.

To provide estimates of source carbon proportions for each elasmobranch species (i.e. the food webs being used) in this system, we used MixSIR (Semmens \& Moore 2008). MixSIR is a Bayesian-mixing model that accounts for variation in isotopic fractionation and sources values (Moore \& Semmens 2008). We assumed 3 resource pools: seagrass, macroalgae, and phytoplankton (estimated using planktivorous bivalves as a proxy). The number of trophic transfers between resource pools and elasmobranchs was estimated by calculating a standardized trophic level for each species with diet data as described by Ebert \& Bizzarro (2007). For species lacking sufficient diet data, trophic level values were estimated from published diet information or from similar species (Darracott 1977, Stead \& Bennett 2008, Schluessel et al. 2010). Isotopic fractionation $\left(\delta^{13} \mathrm{C}: 0.96 \pm 1.68 \%\right.$; $\delta^{15} \mathrm{~N}: 2.75 \pm 1.64 \%$; Caut et al. 2009) was scaled to the number of trophic transfers minus 1 . For the last trophic transfer, we used fractionation values calculated from an elasmobranch $\left(\delta^{13} \mathrm{C}\right.$ : $0.86 \pm 0.28 \%$; $\delta^{15} \mathrm{~N}: 2.43 \pm 0.27 \%$; Hussey et al. 2010 ) One million iterations were used for each species group.

Stomach content processing and analysis. Prey items were identified to the lowest possible taxonomic level, counted, and blotted dry, and all items of a given taxon were weighed collectively. To facilitate analyses, prey were grouped into 9 prey categories (see Table 3). The shrimp-like crustaceans could not be identified due to their size and state of digestion, but appear to all be the same species.

Diets were quantified for each species using 3 measures: frequency of occurrence (\%FO, proportion of stomachs containing prey that contain a given prey category), numerical abundance ( $\% \mathrm{~N}$, proportion of the total number of prey items that belong to a given prey category) and gravimetric abundance (\%W, proportion of the total weight of all prey items that belong to a given prey category). From these 3 measures we calculated the index of relative importance (IRI, Pinkas et al. 1971) for each prey category as IRI $=\% \mathrm{FO} \times(\% \mathrm{~N}$ $+\% \mathrm{~W})$. For interspecific comparisons, the IRI of each prey category was divided by the sum of all IRI values (\%IRI, Cortés 1997). 
Dietary overlap was calculated for $\% \mathrm{~N}, \% \mathrm{~W}$, and \%IRI using Schoener's overlap index (Schoener 1970). Values for this index range from 0 to 1 , with 0 representing no overlap and 1 representing complete overlap. Overlap values of $\geq 0.6$ are generally considered biologically significant (Wallace 1981); however, because this cutoff is arbitrary, we also used null models to determine if overlap values were higher than predicted by chance. The null models create distributions of simulated overlap values by reshuffling the values for each species. Observed values of overlap differ from those predicted by chance if they are in the highest or lowest $2.5 \%$ of the simulated distribution (i.e. $\mathrm{p}<0.05)$. For each null model, we ran 1000 simulations in EcoSim v. 7.72 (Gotelli \& Entsminger 2009) using the RA3 algorithm for randomization (niche breadth retained/zero states reshuffled).

We also calculated $\% \mathrm{~N}$ and $\% \mathrm{~W}$ at the individual level so we could assess dietary differences between species using a 1-way analysis of similarity (ANOSIM). Prior to running the ANOSIM, these data were standardized, square-root transformed and used to construct a Bray-Curtis similarity matrix. Upon finding significant dietary differences between species, we conducted a similarity percentages (SIMPER) analysis to identify which prey categories contributed most to the observed differences. ANOSIM and SIMPER were performed using PRIMER 6.

\section{RESULTS}

\section{Stable isotope analysis}

Relationships between size and isotopic values were found for 3 species. For Glaucostegus typus, the relationship was linear across the whole size range sampled for both $\delta^{13} \mathrm{C}$ (negative relationship) and $\delta^{15} \mathrm{~N}$ (positive relationship) (regression, $t=-2.99, \mathrm{p}=0.005$ and $t=3.81, \mathrm{p}=0.001$, respectively). As a result, we divided $G$. typus into 2 size classes based on the mean size of sampled individuals: $<150 \mathrm{~cm}$ TL and $>150 \mathrm{~cm}$ TL. With the exception of 3 points, $\delta^{13} \mathrm{C}$ and $\delta^{15} \mathrm{~N}$ values for pink whiprays Himantura fai appeared to stabilize once individuals reached a size larger than $65 \mathrm{~cm}$ DW. When the 3 aforementioned points were excluded, there was no relationship between $\delta^{13} \mathrm{C}$ and $\delta^{15} \mathrm{~N}$ values and size for individuals larger than $65 \mathrm{~cm}$ DW (regression, $t=0.35, \mathrm{p}=0.732$ and $t=-1.30, \mathrm{p}=$ 0.204 , respectively), so $H$. fai was split into 2 sizes classes: $\leq 65 \mathrm{~cm} \mathrm{DW}$ and $>65 \mathrm{~cm}$ DW. For cowtail rays Pastinachus atrus, there appeared to be a natural break in the data at a size of $60 \mathrm{~cm} \mathrm{DW}$ for both $\delta^{13} \mathrm{C}$ and $\delta^{15}$ N. For individuals greater than $60 \mathrm{~cm}$ DW there was no relationship between size and $\delta^{15} \mathrm{~N}$ (regression, $t=1.25, \mathrm{p}=0.228$ ), although there was a negative relationship with $\delta^{13} \mathrm{C}$ (regression, $t=-3.57, \mathrm{p}=0.002$ ). Despite the relationship with size and $\delta^{13} \mathrm{C}$, we split $P$. atrus into 2 groups using $60 \mathrm{~cm}$ DW as the dividing point.

Species differed with regard to their average location in isotopic niche space (MANOVA, $F=31.28$, p < 0.001). The observed differences were a result of differences in both $\delta^{13} \mathrm{C}$ and $\delta^{15} \mathrm{~N}$ (ANOVA, $F=32.51, \mathrm{p}<$ 0.001 and $F=24.46$, p $<0.001$, respectively; Fig. 1, Table 1). Glaucostegus typus $<150 \mathrm{~cm}$ TL $\left(\delta^{13} \mathrm{C}=-6.54\right.$ $\pm 0.99 \%$, mean $\pm \mathrm{SD}$ ) was the most enriched in ${ }^{13} \mathrm{C}$, while Chiloscyllium punctatum $\left(\delta^{13} \mathrm{C}=-11.84 \pm\right.$ $1.13 \%$ ) was the least enriched. Rhynchobatus laevis $\left(\delta^{15} \mathrm{~N}=8.90 \pm 0.76 \%\right.$ ) had the highest $\delta^{15} \mathrm{~N}$ value and Neotrygon spp. $\left(\delta^{15} \mathrm{~N}=5.93 \pm 1.04 \%\right.$ ) had the lowest value.

The curves generated to examine the effect of sample size on TA reached an asymptote for the reticulate whipray Himantura uarnak and both size classes of Pastinachus atrus and Glaucostegus typus, indicating that most of the individual variation within isotopic signatures was captured (Fig. 2). An asymptote was also reached for $H$. fai $>65 \mathrm{~cm} \mathrm{DW}$ with and without the 3 anomalous values. Therefore, for these species, sample sizes were likely adequate to estimate $\delta^{13} \mathrm{C}$ range, $\delta^{15} \mathrm{~N}$ range, and TA for the size range examined. For the remaining species examined, $\delta^{13} \mathrm{C}$ range, $\delta^{15} \mathrm{~N}$ range, and TA are likely to be underestimated. Anomalous values, however, may have affected the bootstrap results for the Indo-Pacific spotted eagle ray Aetobatus

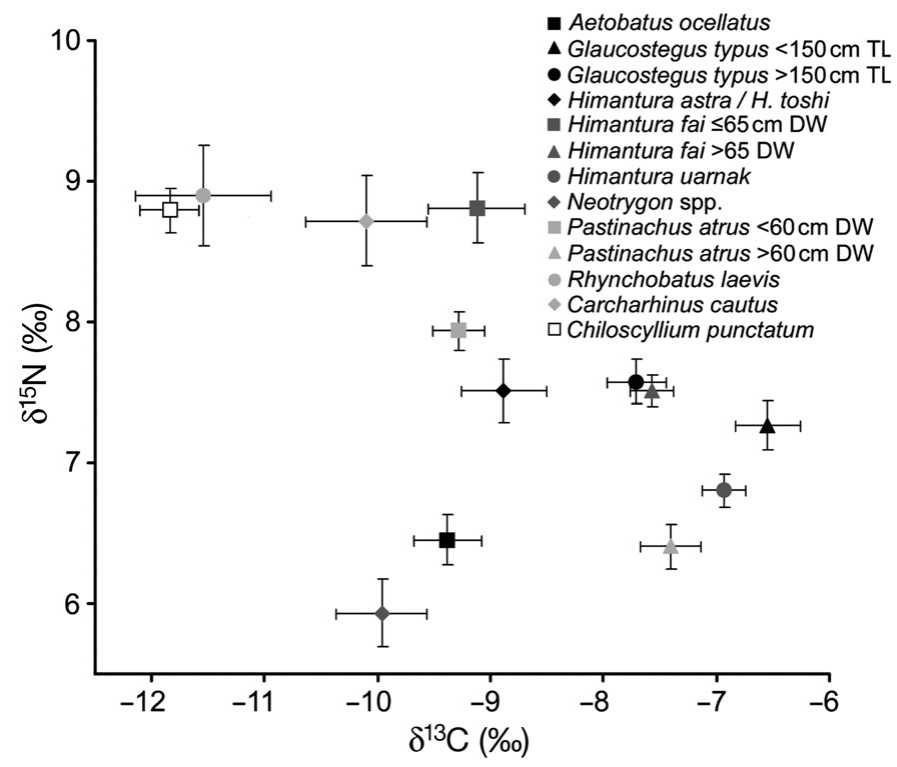

Fig. 1. $\delta^{13} \mathrm{C}-\delta^{15} \mathrm{~N}$ biplot of the nearshore elasmobranch community of Shark Bay (mean $\pm \mathrm{SE}$ ) in isotopic niche space. See Table 1 for statistical contrasts among species. TL: total length; DW: disc width 


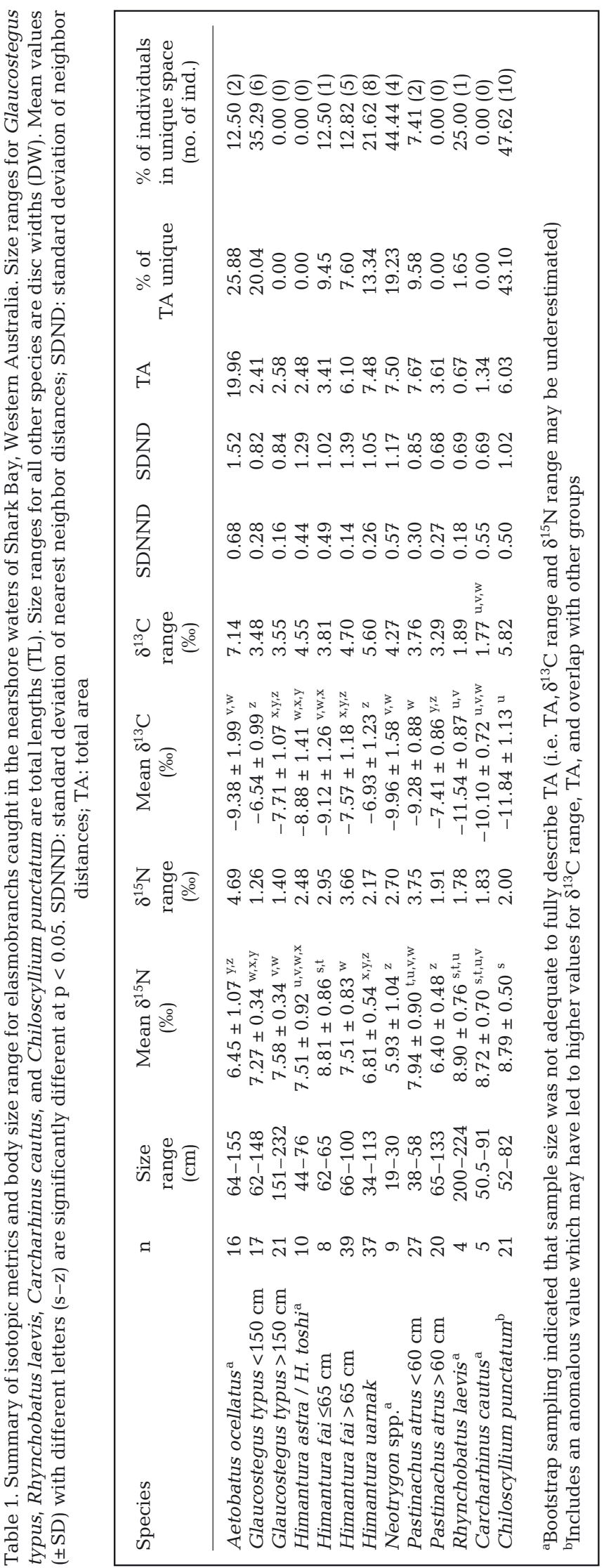

ocellatus (formerly A. narinari) and Chiloscyllium punctatum. Despite a visual inspection that would not indicate values reaching an asymptote for A. ocellatus, variability within the 4 endpoints resulted in a slope that did not differ from zero (regression, $t=2.12, \mathrm{p}=$ 0.168 ). Reanalysis after removal of an individual with an unusually high $\delta^{15} \mathrm{~N}$ value resulted in the endpoints having a slope that differed from zero (regression, $t=$ 7.77, $p=0.016$ ), indicating that an asymptote had not been reached (Fig. 2). For C. punctatum, the slope of the best-fit line through the 4 endpoints differed from zero (regression, $t=8.64, \mathrm{p}=0.013$ ); when an individual with an unusually high $\delta^{13} \mathrm{C}$ value was removed from the bootstrap analysis, the slope no longer differed from zero. Most of the variability within C. punctatum may, therefore, have been sampled.

For the species groups with adequate sample sizes to estimate examined TA, values ranged from 2.41 units $^{2}$ (Glaucostegus typus $<150 \mathrm{~cm}$ DW) to 7.67 units $^{2}$ (Pastinachus atrus $<60 \mathrm{~cm} \mathrm{DW)} \mathrm{(Table} \mathrm{1).} \mathrm{Despite} \mathrm{a} \mathrm{sample}$ size not large enough to adequately describe TA, Aetobatus ocellatus had the largest TA (19.96 units ${ }^{2}$ ) even when the anomalous values were excluded $(12.83$ units $^{2}$ ). The percentage of nonoverlapping space (portion of isotopic niche space based on TA that is not shared with another species group) occupied by each species group ranged from $0 \%$ (Carcharhinus cautus, P. atrus $>60 \mathrm{~cm} \mathrm{DW}, G$. typus $>150 \mathrm{~cm}$ TL and the Himantura astra/H. toshi group) to $43.10 \%$ (Chiloscyllium punctatum) (Table 1, Fig. 3) with the percentage of individuals of a species occupying the nonoverlapping space ranging from $0 \%$ (C. cautus, $P$. atrus $>60 \mathrm{~cm}$ DW, G. typus $>150 \mathrm{~cm} \mathrm{TL}$ and the H. astra/H. toshi group) to $47.62 \%$ (C. punctatum) (Table 1, Fig 3).

Of the adequately sampled groups, $\delta^{13} \mathrm{C}$ ranges varied from $3.29 \%$ (Pastinachus atrus $>60 \mathrm{~cm} \mathrm{DW}$ ) to $5.82 \%$ if all Chiloscyllium punctatum values were included or 5.6\% (Himantura uarnak) if the anomalous C. punctatum was excluded (Table 1). Aetobatus ocellatus had the largest $\delta^{13} \mathrm{C}$ range $(7.14 \%)$ despite the fact that it may be underestimated. A. ocellatus also had the largest range in $\delta^{15} \mathrm{~N}(4.69 \%)$, although this is due to an individual with an unusually large $\delta^{15} \mathrm{~N}$ value. For groups with adequate sample sizes, the smallest $\delta^{15} \mathrm{~N}$ range belonged to Glaucostegus typus $<150 \mathrm{~cm}$ TL $(1.26 \%$; Table 1$)$ and $P$. atrus $<60 \mathrm{~cm} \mathrm{DW}$ had the largest range. With the exception of A. ocellatus, all groups had similar CD values (ANOVA, $F=$ $3.00, p=0.001$; Fig. 4). We found a greater number of interspecies differences in NND (ANOVA, $F=6.64, \mathrm{p}<$ 0.001; Fig. 4) and ND (ANOVA, $F=18.92, p=0.001$; Fig. 4). SDNND ranged from 0.14 units (H. fai $>65 \mathrm{~cm}$ DW) to 0.68 units (A. ocellatus; Table 1 ) and SDND ranged from 0.68 units ( $P$. atrus $>60 \mathrm{~cm}$ DW) to 1.52 units (A. ocellatus; Table 1). 

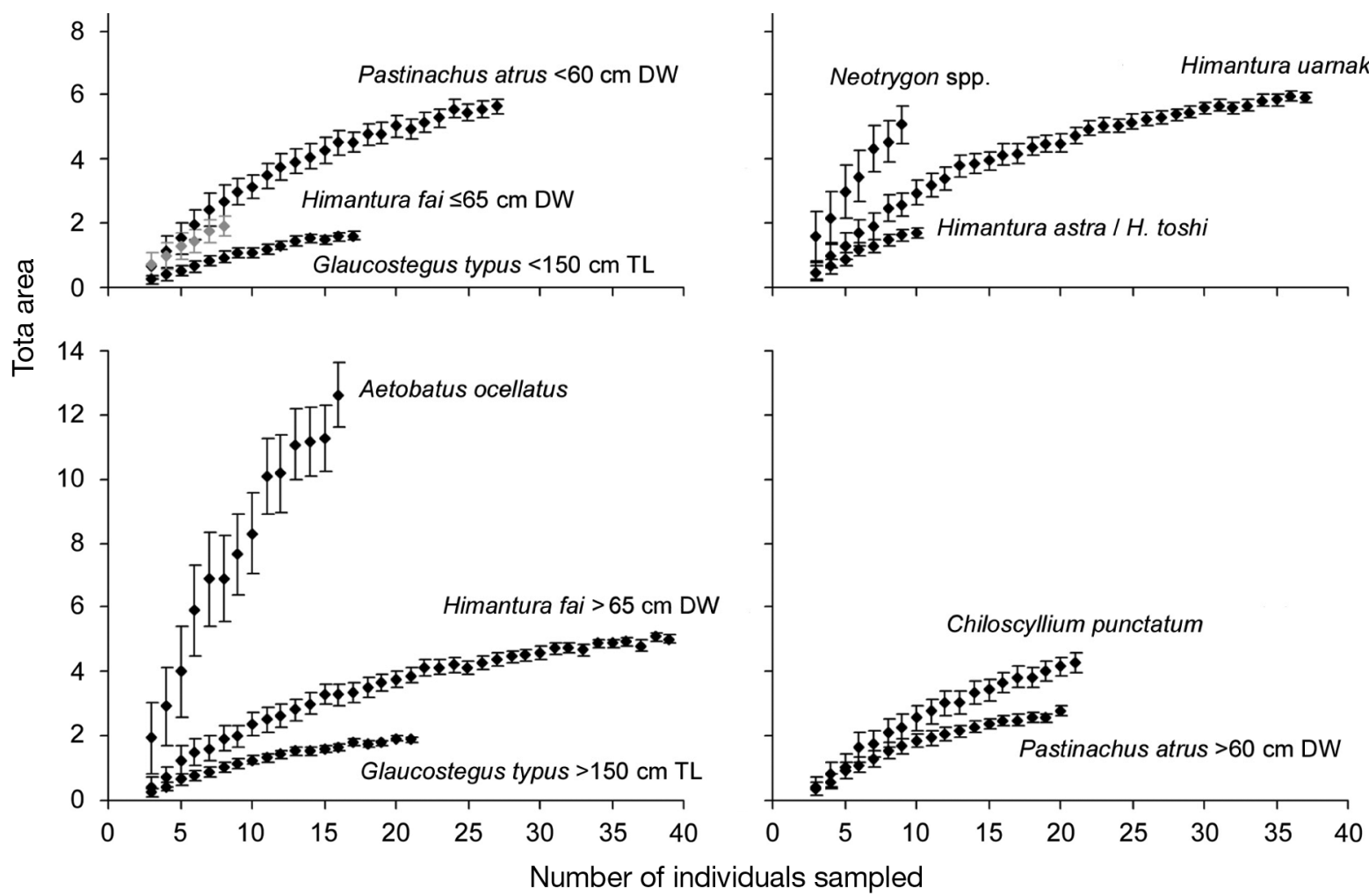

Fig. 2. Size of isotopic niche space (total area: mean \pm SE) from bootstraps in relation to the number of individuals sampled for the nearshore elasmobranch community of Shark Bay. Himantura fai $\leq 65 \mathrm{~cm}$ DW (disc width) is shown in gray to increase its visibility

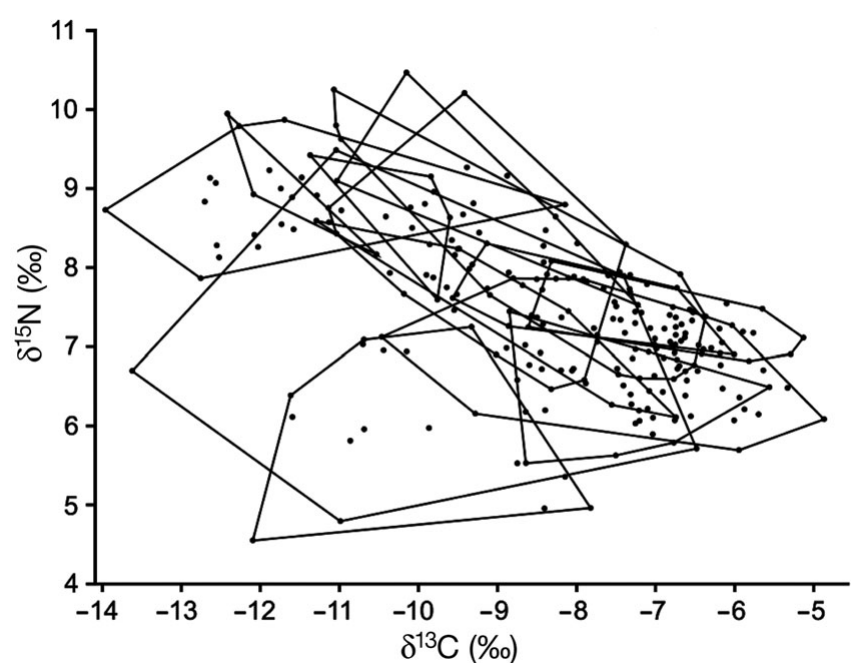

Fig. 3. All elasmobranch individuals plotted in isotopic niche space. Black lines outline the convex hulls of the individual groups illustrating a high degree of overlap in isotopic niche space

Based on published estimates of isotopic fractionation, calculated elasmobranch trophic levels and the assumption that elasmobranchs are limited to phytoplankton, algal and seagrass resource pools in Shark Bay, most of the elasmobranchs examined are highly dependent on the seagrass-based food web. The median contribution of the seagrass resource pool to elasmobranchs ranged from $35 \%$ (Chilosyllium punctatum) to $85 \%$ (Glaucostegus typus $<150 \mathrm{~cm} \mathrm{TL}$ ) and for 10 of the 13 groups, seagrass contribution exceeded $50 \%$ (Table 2). In the 3 species divided into size classes, the contribution from the seagrass food web increased with size for Pastinachus atrus and Himantura fai, while it decreased for $G$. typus.

\section{Stomach content analysis}

We recovered stomach contents from 114 individuals (17 Glaucostegus typus $<150 \mathrm{~cm}$ TL, 34 G. typus $>150 \mathrm{~cm}$ TL, 10 Himantura fai $\leq 65 \mathrm{~cm}$ DW, $27 \mathrm{H}$. fai $>65 \mathrm{~cm} \mathrm{DW}, 14 \mathrm{H}$. uarnak, 6 Pastinachus atrus, and 6 H. astra/H. toshi). The proportion of lavaged individuals from which we collected stomach contents was similar across species (63\% G. typus $<150 \mathrm{~cm} \mathrm{TL}, 72 \%$ G. typus $>150 \mathrm{~cm} \mathrm{TL}, 100 \%$ H. fai $\leq 65 \mathrm{~cm} \mathrm{DW}, 75 \%$ H. fai $>65 \mathrm{~cm} \mathrm{DW}, 69 \%$ H. uarnak, $60 \%$ P. atrus, and $75 \%$ H. astra/H. toshi).

Due to small sample sizes for Himantura astra/ H. toshi and Pastinachus atrus, quantitative analyses were only performed for $H$. fai $\leq 65 \mathrm{~cm} \mathrm{DW,} \mathrm{H.} \mathrm{fai}$ $>65 \mathrm{~cm}$ DW, H. uarnak, Glaucostegus typus $<150 \mathrm{~cm}$ 

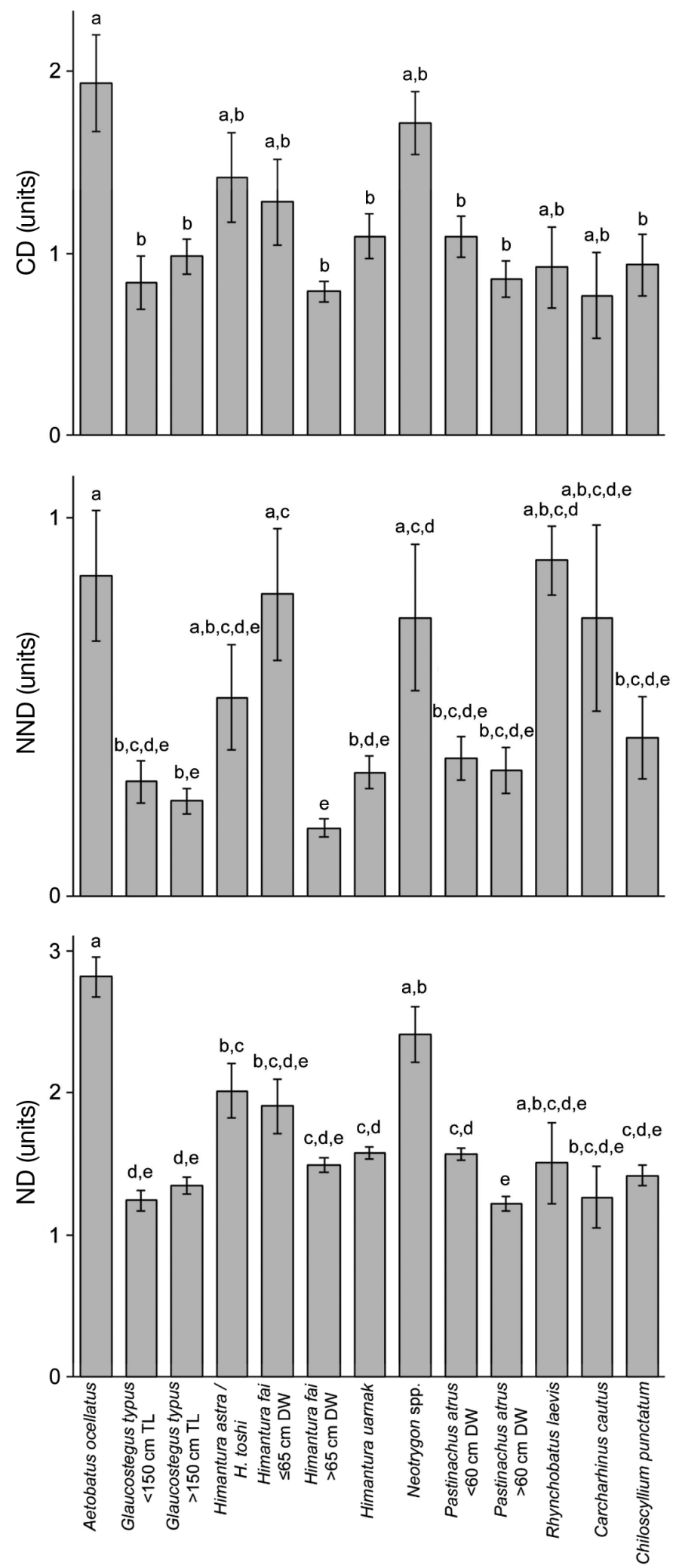

Fig. 4. Centroid distance (CD), nearest neighbor distance (NND), and neighbor distance (ND) (mean distance \pm SE) for the nearshore elasmobranch community of Shark Bay. Values with different letters are significantly different at $\mathrm{p}<0.05$. TL: total lenghth; DW: disc width
TL and G. typus $>150 \mathrm{~cm}$ TL. For these species groups, crustaceans dominated the diet for all 4 metrics. In particular, penaeid shrimp appear to be quite important; they were found in $>60 \%$ of samples from each species group (Table 3). In addition, for $H$. uarnak, $H$. fai (both sizes classes) and $G$. typus $<150 \mathrm{~cm}$ TL, penaeids made large contributions to $\% \mathrm{~N}, \% \mathrm{~W}$, and \%IRI (Table 3). Penaeids and brachyuran crabs made similar contributions to the diets of G. typus $<150 \mathrm{~cm} \mathrm{TL}$, and brachyurans dominated the diet of G. typus $>150 \mathrm{~cm}$ TL based on \%IRI (Table 3). Crabs were found in $82 \%$ of $G$. typus samples (both size classes) and despite making up $10 \%(<150 \mathrm{~cm} \mathrm{TL})$ and $6 \%(>150 \mathrm{~cm}$ TL) of prey items by number, they composed $51 \%(<150 \mathrm{~cm}$ TL) and $67 \%$ (>150 cm TL) of prey items by weight (Table 3). Portunid crabs made up the majority of crabs consumed by all 3 species, but adult blue crabs Portunus pelagicus were only found in the contents of G. typus. Additionally, shrimp-like crustaceans $(\sim 1 \mathrm{~cm}$ in length) were only found in G. typus and in large numbers, making them the most numerous prey items in the diets of G. typus (both size classes). Prey items collected from the stomachs of $H$. astra/H. toshi matched those of the other Himantura spp., while the stomach contents of $P$. atrus differed dramatically. Polychaetes, including tubeworms, made up the bulk of collected $P$. atrus stomach contents and holothuroideans were also collected; holothuroideans were not found in the contents of any other species.

We found high values of dietary overlap between Himantura uarnak and both size classes of $H$. fai. Overlaps between the 3 groups for $\% \mathrm{~N}$ and \%IRI were biologically significant (Schoener's index $>0.6$; Table 4) as was the overlap in \%W between both size classes of $H$. fai. Overlaps in \%W between both size classes of $H$. fai and $H$. uarnak were much lower due to the higher mass of polychaetes found in H. uarnak. The polychaetes found in stomachs of $H$. uarnak, however, all came from 1 individual. Removal of this individual from the data set resulted in significant overlap in \% Wetween $H$. uarnak and both sizes classes of $H$. fai $(H$. fai $\leq 65 \mathrm{~cm}$ DW: Schoener's index $=0.89$ and $H$. fai > 65 cm DW: Schoener's index $=0.76$ ). Null models confirmed that $\% \mathrm{~N}$ overlap values between $H$. fai size classes, overlap values between $H$. fai size classes and $H$. uarnak for $\% \mathrm{~N}$ and overlap values for $H$. fai $\leq 65 \mathrm{~cm}$ DW and $H$. uarnak for \%IRI were higher than predicted by chance (Table 4 ). When the H. uarnak containing the large mass of polychaetes was removed, the overlap value for \%W between $H$. uarnak and $H$. fai $\leq 65 \mathrm{~cm}$ DW was higher than predicted by chance ( $\mathrm{p}<0.001)$, but the overlap in \%W for $H$. uarnak and H. fai $>65 \mathrm{~cm}$ DW was not $(\mathrm{p}=0.118)$. Neither Himantura spp. showed high overlap with either size class of Glaucostegus typus for any metric (Table 4), nor were 
Table 2. Estimated trophic positions of and median (5th to 95th percentile) contributions of basal resource pools to elasmobranchs caught in the nearshore waters of Shark Bay, Western Australia. Resource pool values used for the MixSIR model are shown below. Filter-feeding bivalves were used as a proxy for the phytoplankton resource pool and considered one trophic level higher than the basal level (i.e. trophic level 2)

\begin{tabular}{|lccrr|}
\hline Species & $\begin{array}{c}\text { Estimated } \\
\text { trophic level }\end{array}$ & Phytoplankton & $\begin{array}{c}\text { Resource pool } \\
\text { Algae }\end{array}$ & Seagrass \\
\cline { 3 - 5 } & 3.16 & $0.15(0.02-0.27)$ & $0.14(0.02-0.32)$ & $0.71(0.61-0.80)$ \\
Aetobatus ocellatus & 3.50 & $0.05(0.00-0.14)$ & $0.09(0.01-0.21)$ & $0.85(0.75-0.93)$ \\
Glaucostegus typus $(<150 \mathrm{~cm})$ & 3.51 & $0.08(0.01-0.20)$ & $0.17(0.03-0.29)$ & $0.74(0.66-0.83)$ \\
Glaucostegus typus $(>150 \mathrm{~cm})$ & 3.53 & $0.16(0.03-0.31)$ & $0.17(0.02-0.37)$ & $0.66(0.54-0.78)$ \\
Himantura astra $/ \mathrm{H}$ toshi & 3.52 & $0.14(0.02-0.30)$ & $0.27(0.05-0.48)$ & $0.59(0.43-0.74)$ \\
Himantura fai $(\leq 65 \mathrm{~cm})$ & 3.52 & $0.07(0.01-0.17)$ & $0.16(0.05-0.26)$ & $0.77(0.70-0.84)$ \\
Himantura fai $(>65 \mathrm{~cm})$ & 3.53 & $0.06(0.01-0.14)$ & $0.10(0.01-0.19)$ & $0.84(0.78-0.91)$ \\
Himantura uarnak & 3.53 & $0.25(0.07-0.38)$ & $0.08(0.01-0.27)$ & $0.65(0.55-0.78)$ \\
Neotrygon spp. & 3.53 & $0.20(0.09-0.31)$ & $0.19(0.07-0.33)$ & $0.63(0.53-0.68)$ \\
Pastinachus atrus $(<60 \mathrm{~cm})$ & 3.53 & $0.09(0.01-0.19)$ & $0.09(0.01-0.21)$ & $0.81(0.73-0.90)$ \\
Pastinachus atrus $(>60 \mathrm{~cm})$ & 3.78 & $0.41(0.15-0.62)$ & $0.22(0.03-0.52)$ & $0.36(0.18-0.54)$ \\
Rhynchobatus laevis & 4.10 & $0.31(0.09-0.51)$ & $0.18(0.02-0.45)$ & $0.49(0.33-0.66)$ \\
Carcharhinus cautus & 3.78 & $0.48(0.37-0.58)$ & $0.18(0.06-0.29)$ & $0.35(0.28-0.42)$ \\
Chiloscyllium punctatum & Resource pool values & Filter-feeding bivalves & Algae & Seagrass \\
& $\delta^{13} \mathrm{C}(\%)$ (mean $\left.\pm \mathrm{SD}\right)$ & $-17.49 \pm 1.70$ & $-15.47 \pm 2.58$ & $-9.41 \pm 1.32$ \\
& $\delta^{15} \mathrm{~N}(\%)$ (mean \pm SD) & $4.39 \pm 0.68$ & $3.52 \pm 0.74$ & $0.77 \pm 1.62$ \\
\hline
\end{tabular}

values higher than predicted by chance (Table 4). High values of overlap for all indices were found between the 2 size classes of G. typus and were supported by null models (Table 4).

Using ANOSIM, we found differences in the dietary compositions by numerical abundance between $\mathrm{Hi}$ mantura fai $>65 \mathrm{~cm}$ DW and both Glaucostegus typus size classes (G. typus $<150 \mathrm{~cm}$ TL: $\mathrm{R}=0.479, \mathrm{p}<0.001$ and G. typus $>150 \mathrm{~cm}$ TL: $\mathrm{R}=0.209, \mathrm{p}<0.001)$. SIMPER analysis revealed that differences in the abundance of penaeid shrimp (27.9\% of dissimilarity), shrimp-like crustaceans $(25.0 \%$ of dissimilarity) and brachyuran crabs $(21.5 \%$ of dissimilarity) contributed the most to the observed difference between $H$. fai $>65 \mathrm{~cm}$ DW and G. typus $<150 \mathrm{~cm}$ TL. Penaeids and brachyurans ( $34.0 \%$ and $25.8 \%$ of dissimilarity, respectively) contributed the most to differences between $H$. fai $>65 \mathrm{~cm}$ DW and G. typus $>150 \mathrm{~cm}$ TL. H. fai $\leq 65 \mathrm{~cm} \mathrm{DW}$ and H. uarnak also differed from $G$. typus $<150 \mathrm{~cm}$ TL $(\mathrm{R}=$ $0.324, p=0.004$ and $\mathrm{R}=0.310, \mathrm{p}=0.002$, respectively). G. typus $<150 \mathrm{~cm}$ TL differences from $H$. fai $\leq 65 \mathrm{~cm}$ DW and $H$. uarnak were primarily due to differences in abundances of penaeids (31.9 and $27.8 \%$ of dissimilarity, respectively), shrimp-like crustaceans (27.1 and $26.3 \%$ of dissimilarity, respectively) and brachyurans (26.1 and $22.7 \%$ of dissimilarity, respectively). Analysis by weight revealed that differences existed between all Himantura groups and both G. typus size classes (ANOSIM, R $=0.185$ to $0.408, \mathrm{p}=0.001$ to 0.032 ). Brachyuran crabs and penaeid shrimp contributed the most to the observed differences, making up 30.1 to $41.5 \%$ of the observed dissimilarities.

\section{DISCUSSION}

Despite the diversity and abundance of the nearshore elasmobranch community of Shark Bay (Vaudo \& Heithaus 2009), many of the species appear to occupy similar trophic positions based on their diets. In fact, most species occupied very little unique isotopic niche space (TA), although mean isotopic values did differ between species. In addition, mixing models suggest that most of the elasmobranch community is highly dependent on a seagrass carbon source. Prey, however, may not necessarily come from the seagrass beds. Many invertebrates from the sandflats, including shrimp, have $\delta^{13} \mathrm{C}$ values similar to those of seagrass (M. R Heithaus unpubl. data), indicating that seagrass may provide an important carbon source for the sandflats via detrital pathways. However, despite the number of elasmobranch, especially batoid, sightings and batoid feeding pits on the nearshore sandflats during the warm season (September to May; Vaudo \& Heithaus 2009), seagrass beds may provide the primary foraging grounds for this elasmobranch community based on the depauperate sandflat prey base of Shark Bay (Wells et al. 1985, Black et al. 1990) and stomach content analysis (see below). The fact that the seagrass beds in Shark Bay may be supporting a diverse and abundant batoid community further emphasizes the importance of seagrass bed production in marine systems (Heck et al. 2008) and, in this system, extends it to a group of species that are not typically associated with seagrass.

However, despite the overall similarity in mean isotopic niche position and high degree of overlap in 


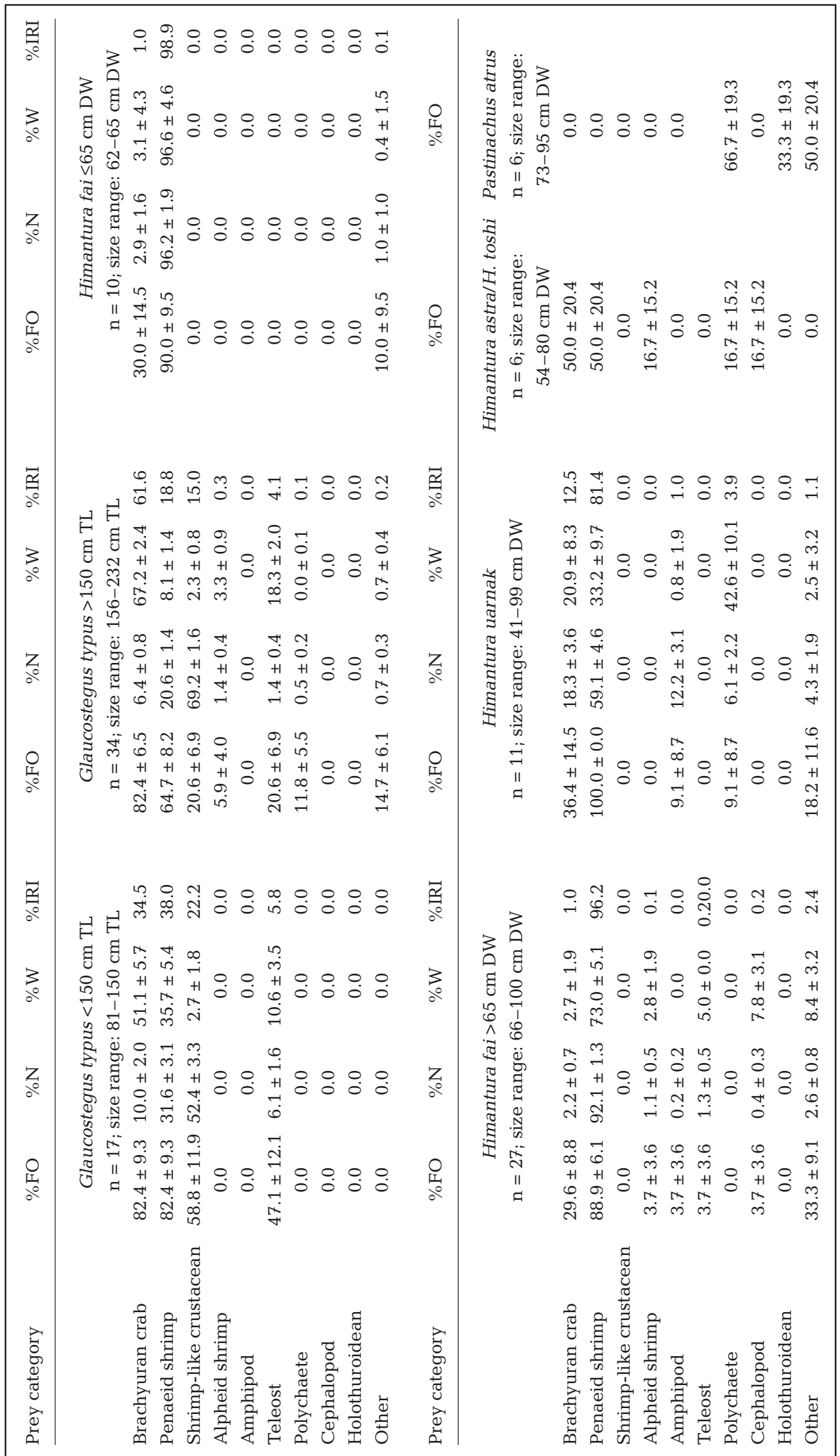


Table 4. Pairwise comparisons of the diets for Glaucostegus typus, Himantura fai, and H. uarnak. Values for Schoener's index of overlap $(\% \mathrm{~N} / \% \mathrm{~W} / \% \mathrm{IRI}$, see Table 3) are in the lower half of the matrix. Bold values are considered biologically significant (>0.60). p-values from null model simulations are in the upper half of the matrix. Bold values indicate that corresponding overlap values in the lower matrix are higher than those predicted by chance. TL: total length; DW: disc width

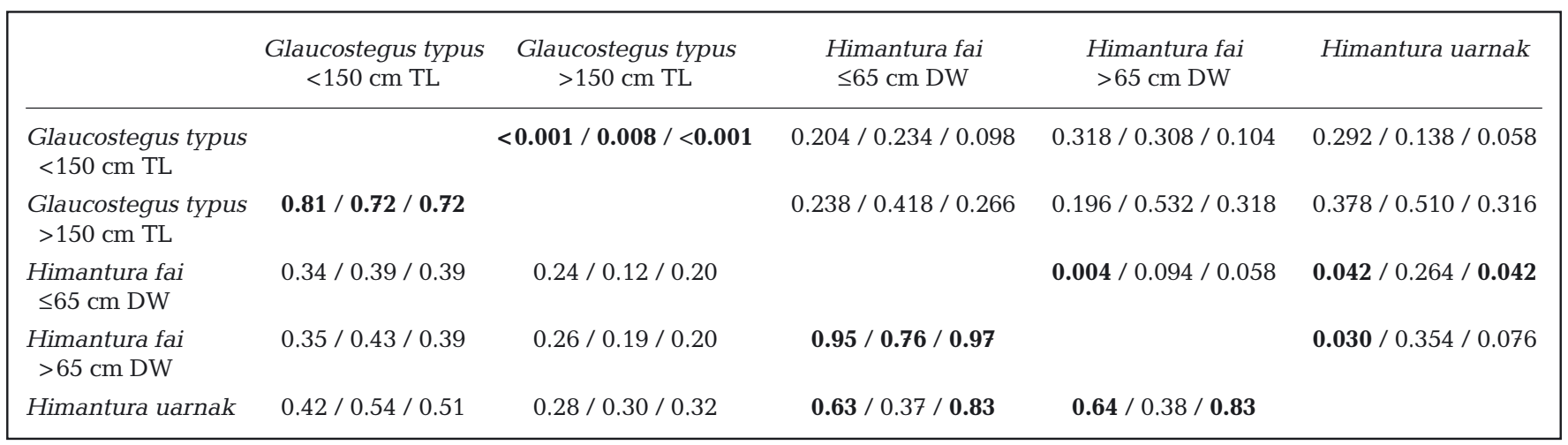

observed $\delta^{15} \mathrm{~N}$ and $\delta^{13} \mathrm{C}$ values, subtle differences were observed between species. Not surprisingly, the Neotrygon spp. and Aetobatus ocellatus on average had lower $\delta^{15} \mathrm{~N}$, often indicative of feeding at a lower trophic level. The Neotrygon spp. are much smaller than the other batoids in the system (maximum size = $\sim 30 \mathrm{~cm}$ DW) and as such are limited to smaller prey (Darracott 1977), which are generally low level consumers. A. ocellatus, on the other hand, tends to be one of the larger batoids observed in the nearshore flats, growing to over $3 \mathrm{~m}$ DW (usually less than $2 \mathrm{~m}$ DW within our study site), but tends to feed on low-order consumers such as gastropods and bivalves (Schluessel et al. 2010). Feeding on such low-level consumers should result in the lower $\delta^{15} \mathrm{~N}$ values observed. The high contribution of the seagrass resource pool in $A$. ocellatus could mean that individuals in Shark Bay are not as dependent on bivalve prey as previously thought or that the bivalves eaten are detritivores. Several detritivorous bivalves are found in the shallow waters of Shark Bay. Further diet studies on A. ocellatus in Shark Bay are required to investigate these possibilities.

Albeit based on only 4 individuals, Rhynchobatus laevis had the highest $\delta^{15} \mathrm{~N}$ values and the lowest $\delta^{13} \mathrm{C}$ values of the batoids examined. Mixing models suggest that these values may be the result of $R$. laevis being less dependent on the seagrass food web than other batoids in the system. $R$. laevis is also a large mobile species (up to $3 \mathrm{~m}$ TL) with a body that more closely resembles pelagic sharks than it does most batoids, and as a result its size and motility open up the possibility of it feeding on larger more mobile prey, which may have higher $\delta^{15} \mathrm{~N}$ values than smaller benthic prey species; teleost prey have frequently been found in the diet of congeners (Darracott 1977). In addition, it is the only species examined that we have not observed in the study area during the cold season (June to August; Vaudo \& Heithaus 2009), so its isotopic signature is reflective of prey not only from the study site, but also from areas where it spends the rest of the year, which may exhibit different baseline carbon and nitrogen values.

The 2 shark species from the shallow flats tended to have higher $\delta^{15} \mathrm{~N}$ values and lower enrichment of ${ }^{13} \mathrm{C}$, although their values were not distinct from many of the batoid species. The trend toward higher $\delta^{15} \mathrm{~N}$ values for Carcharhinus cautus and Chiloscyllium punctatum is likely the result of the higher proportion of fish in their diets. Teleosts make up $\sim 70 \%$ of the diet of C. cautus by number and volume in Shark Bay (White et al. 2004) and $\sim 30 \%$ of the IRI of C. punctatum in other locations (Stead \& Bennett 2008), although the mixing models also suggest that these species are less reliant than the batoids examined on the seagrass food web, which had a lower $\delta^{15} \mathrm{~N}$ baseline.

Interestingly, isotopic values from the most common elasmobranchs (Glaucostegus typus, Himantura spp., and Pastinachus atrus) on the nearshore flats of Shark Bay were similar, although there were differences between species groups with regard to mean $\delta^{15} \mathrm{~N}$ and $\delta^{13} \mathrm{C}$ values. $H$. fai $\leq 65 \mathrm{~cm} \mathrm{DW}$ and $P$. atrus $>60 \mathrm{~cm} \mathrm{DW}$ had the highest and lowest $\delta^{15} \mathrm{~N}$ values of these groups, respectively, and differed by $2.4 \%$. The $\delta^{15} \mathrm{~N}$ range of the rest of these elasmobranchs was only $1.1 \%$, emphasizing their similarity. The $\delta^{13} \mathrm{C}$ range of these common elasmobranchs was $2.7 \%$, with G. typus $<150 \mathrm{~cm}$ TL the most enriched in ${ }^{13} \mathrm{C}$ and $P$. atrus $<60 \mathrm{~cm}$ DW the least enriched.

Despite the abovementioned similarities, we did find isotopic differences between size classes for 2 of the 3 species divided by size. Pastinachus atrus size classes differed in both $\delta^{15} \mathrm{~N}$ and $\delta^{13} \mathrm{C}$ values, while Himantura fai size classes only differed in $\delta^{15} \mathrm{~N}$ values. For both 
species, the smaller size classes were more enriched in ${ }^{15} \mathrm{~N}$ and mixing models suggested an increased reliance on seagrass carbon with increased size, implying an ontogenetic shift in foraging behavior. Like many fish species, such shifts have been observed in batoids using stomach content analysis (e.g. Bizzarro et al. 2007, Marshall et al. 2008).

The high overlap in isotopic niche space and dependence on seagrass-derived carbon observed for the most common species based on stable isotope analysis were supported by traditional stomach content analysis. With the exception of Pastinachus atrus stomach contents, the breadth of species found in the stomach contents of Glaucostegus typus and the Himantura spp. (all size classes) was similar and these prey species are not typically found on the sandflats of Shark Bay (Wells et al. 1985, Black et al. 1990, J. J. Vaudo unpubl. data). Some of the species, such as juvenile penaeid shrimp, which made up large proportions of the diets of G. typus, H. fai, and H. uarnak, are well established seagrass-associated species (Coles et al. 1987, Kenyon et al. 1997) and previous work in Shark Bay has shown that crustaceans are common in seagrass habitats and rare on the sandflats (Wells et al. 1985). Even though diet breadth was similar for G. typus and the Himantura spp., there was some evidence of resource partitioning. Diet overlap was low between $G$. typus and both Himantura spp. for all size classes due to the differences in the proportions of prey categories consumed, although overlap was higher than expected by chance for G. typus $<150 \mathrm{~cm}$ TL and both $H$. fai $\leq 65$ cm DW and $H$. uarnak. Both size classes of G. typus consumed a larger proportion of crabs and because of its larger size, G. typus $>150 \mathrm{~cm}$ TL was able to make use of a resource not available to the Himantura spp.: adult blue crabs Portunis pelagicus. Similar partitioning of food resources has been noted in several sympatric elasmobranchs, including batoids (Platell et al. 1998, White et al. 2004, Marshall et al. 2008).

Within a species, dietary overlap was high and greater than predicted by chance. Despite the high overlap and indistinguishable $\delta^{15} \mathrm{~N}$ and $\delta^{13} \mathrm{C}$ values between size classes, Glaucostegus typus may experience an ontogenetic shift in diet; crabs were almost twice as important in the diets of larger individuals. This diet shift is consistent with a previous study on the diet of G. typus (White et al. 2004). Despite a difference in the $\delta^{15} \mathrm{~N}$ values of Himantura fai, we were not able to detect evidence of an ontogenetic diet shift based on stomach contents. This may be a result of the small number of $H$. fai $<65 \mathrm{~cm}$ DW stomachs examined or could possibly reflect habitat differences in the bay, such that prey items (i.e. penaeid shrimp) are more dependent on the algal carbon pool in areas used by small H. fai.
Although sample sizes were small, the presence of tubeworms and sea cucumbers from the sandflats and absence of crustaceans in Pastinachus atrus $>60 \mathrm{~cm}$ DW stomach contents suggests that $P$. atrus $>60 \mathrm{~cm}$ DW forages differently than other batoids in the system, including $P$. atrus $<60 \mathrm{~cm}$ DW, which differed isotopically from larger individuals. It may also explain the large number of foraging pits found on the sandflats during the warm season and the different jaw morphology of this species. However, despite foraging on soft-bodied invertebrates, $P$. atrus $>60 \mathrm{~cm}$ DW had similar nitrogen and carbon values to Himantura uar$n a k$, which feeds predominantly on crustaceans. The isotopic similarity of these species despite dietary differences underscores the importance of using these methods together during studies of foraging ecology because several types of diet can lead to similar and indistinguishable positions in isotopic niche space. In this case, stable isotopic analysis suggests that $P$. atrus $>60 \mathrm{~cm}$ DW and H. uarnak are both dependent on seagrass-derived carbon and may occupy similar trophic levels, but cannot differentiate between the diets of these 2 species or the habitats in which they feed.

Many studies have found that resource partitioning is a common feature within marine fish communities (e.g. Beyst et al. 1999, Darnaude et al. 2001, Guedes \& Araujo 2008). For example, Platell \& Potter (2001) examined a guild of 18 benthic carnivores and found that in only 1 of 153 pairwise diet comparisons species did not differ and those 2 species occupied different depth distributions. Dietary partitioning is also well established in several elasmobranch species (e.g. White et al. 2004, Marshall et al. 2008), including sympatric, congeneric batoids (Platell et al. 1998). Although differences in diet and isotopic niche space were observed for some species and size classes, given the abundance and diversity of batoids in Shark Bay, the similarity in isotopic niche space and diet breadth within this guild of predators is surprising.

High values of dietary overlap within a guild of sympatric predators would suggest that prey are not limiting. Several studies have found that dietary breadth is inversely related to prey abundances, with predator diets skewed toward abundant prey species and competition relaxed when prey are abundant, leading to dietary similarity (Croxall et al. 1999, Tinker et al. 2008). Such occurrences happen seasonally in some systems, as prey species undergo dramatic seasonal pulses in abundance (e.g. Lucena et al. 2000). Although present in Shark Bay year round, batoids are only abundant on the nearshore flats and therefore catchable during the warm season (September to May; Vaudo \& Heithaus 2009), so we were unable to examine if the diets of batoids in Shark Bay only converge seasonally. 
Alternatively, if batoid populations are below that which could be supported by prey resources, prey may effectively be an unlimited resource throughout the year. Shark Bay is a relatively pristine system and is home to large populations of batoid predators (tiger and hammerhead sharks). Risk and direct predation effects from predators can maintain consumer populations below the carrying capacity set by the consumer's prey (Creel et al. 2007, Heithaus et al. 2008), and if this is the case in Shark Bay, batoid populations may be released from prey limitation, allowing for dietary convergence at the population level and maintaining high levels of batoid diversity.

Similarities at the group level, however, may mask underlying individual variation within each group. Although often ignored, individual variation appears to be a common feature in many systems (Bolnick et al. 2003) and isotopic values suggest that varying levels of individual specialization are found within the batoid populations of Shark Bay. Although inherent variability of isotope values (i.e. variability due to physiological differences in diet-tissue fraction between individuals rather than dietary differences) has not been explicitly examined in elasmobranchs, the observed variation in $\delta^{15} \mathrm{~N}$ and $\delta^{13} \mathrm{C}$ for Shark Bay elasmobranchs exceeds the variation observed in fish species such as the European sea bass Dicentrarchus labrax under controlled conditions (e.g. Sweeting et al. 2007, Barnes et al. 2008); this suggests that the variation in elasmobranch isotope values is due to dietary differences between individuals. The fin tissue used for isotopic analysis should turn over at a slower rate compared to more metabolically active tissues such as blood or muscle, which turn over slowly in elasmobranchs (0.0083 and $0.0041 \mathrm{~d}^{-1}$, respectively; MacNeil et al. 2006) and therefore represent a long-term average of assimilated materials. As a result, differences in isotopic values should represent long-term consistent dietary differences, further suggesting individual specialization within these populations. Bootstrap techniques suggest that even more variation, and thus greater individual specialization, exists within this community for many species.

The amount of trophic diversity (CD), density (NND and ND) and evenness (SDNND and SDND) in trophic space, all measures that provide insight into individual specialization, were similar across groups, with some exceptions. Groups with low sample sizes and those that were not adequately sampled according to bootstrap analysis, including Aetobatus ocellatus and multispecies groups, tended to show the most individual specialization in isotopic values (higher values of CD, NND, ND, SDNND and SDND). This may be a result of sample size (i.e. not enough sampling to fill in the gaps) or the fact that groups contained multiple species, or in the case of A. ocellatus, may reflect increased plasticity due to jaw morphology. A. ocellatus is the only species examined that has plate-like teeth capable of crushing bivalve and gastropod shells, allowing for a more variable diet.

While individual specialization is generally thought to reduce competition, the individual variability observed in isotopic values results in high degrees of overlap between species and limited areas of unique isotopic niche space, despite differences between species means. This suggests that analyses focusing on central tendency may be misleading and miss important population aspects such as individual variation and a large degree of overlap in species isotopic niche spaces. We advocate the use of stable isotope metrics, such as those presented by Layman et al. (2007a), at the population or subpopulation level because they can elucidate often ignored intrapopulation variability (Layman et al. 2007a) and would facilitate comparisons within systems that could provide new insights into food web dynamics and the implications of declines in top predators or other anthropogenic changes to communities (e.g. Layman et al. 2007b). The high degree of variability also underscores a need to be mindful of sample size. Sample size has been shown to be an important concern in isotopic studies of ontogenetic shifts in trophic position (Galván et al. 2010) and, as seen in this study, isotopic metrics such as $\delta^{13} \mathrm{C}$ range, $\delta^{15} \mathrm{~N}$ range, and TA may also be sensitive to sample size. Some of the species groups examined were not adequately sampled to capture the full extent of the group's variability. This is particularly important for large predators, for which conclusions are often made from small sample sizes due to logistical concerns.

Overall, we found that despite its diversity, the elasmobranch community of the nearshore sandflats of Shark Bay occupies a relatively small area of isotopic niche space within the Shark Bay food web and is heavily dependent on seagrass-derived carbon. Within this isotopic niche space, we found that isotopic differences and dietary differences exist between species, although the batoid species examined consumed the same prey. Isotope values and diet data also suggest that individual specialization, although rarely considered in elasmobranchs (Heithaus et al. 2010, but see Matich et al. 2010), may play an important role in the foraging ecology of elasmobranchs and may be crucial to understanding the ecological role of these predators.

Acknowledgements. We thank everyone who helped with the collection and processing of isotopic samples, especially D. Heithaus, K. Gastrich, M. Dunphy-Daly, and D. Burkholder. We also thank the Department of Environment and Conservation, Shark Bay District, R. McAuley of the Department of Fisheries, Western Australia, and the Monkey Mia Dolphin Resort for logistical support, and C. Layman for comments on a previ- 
ous draft of the manuscript. This research was possible due to a Florida International University Presidential Fellowship to J.J.V., a grant from the National Geographic Expeditions Council to J.J.V., National Science Foundation grants OCE0526065 and OCE0745606 to M.R.H., and Florida International University's College of Arts and Sciences. This is contribution no. 47 of the Shark Bay Ecosystem Research Project.

\section{LITERATURE CITED}

Barnes C, Jennings S, Polunin NVC, Lancaster JE (2008) The importance of quantifying inherent variability when interpreting stable isotope field data. Oecologia 155:227-235

Beyst B, Cattrijsse A, Mees J (1999) Feeding ecology of juvenile flatfishes of the surf zone of a sandy beach. J Fish Biol 55:1171-1186

Bizzarro JJ, Robinson HJ, Rinewalt CS, Ebert DA (2007) Comparative feeding ecology of four sympatric skate species off central California, USA. Environ Biol Fishes 80: $197-220$

Black R, Robertson AI, Peterson CH, Peterson NM (1990) Fish and benthos of near-shore seagrass and sandflat habitats at Monkey Mia Shark Bay, Western Australia. In: Berry PF, Bradshaw SD, Wilson BR (eds) Research in Shark Bay: report of the France-Australe Biocentenary Expedition Committee. Western Australia Museum, Perth, p 245-261

Bolnick DI, Svanback R, Fordyce JA, Yang LH, Davis JM, Hulsey CD, Forister ML (2003) The ecology of individuals: incidence and implications of individual specialization. Am Nat 161:1-28

Caut S, Angulo E, Courchamp F (2009) Variation in discrimination factors $\left(\Delta^{15} \mathrm{~N}\right.$ and $\left.\Delta^{13} \mathrm{C}\right)$ : the effect of diet isotope values and applications for diet reconstruction. J Appl Ecol 46:443-453

> Coles RG, Lee Long WJ, Squire BA, Squire LC, Bibby JM (1987) Distribution of seagrasses and associated juvenile commercial penaeid prawns in north-eastern Queensland waters. Aust J Mar Freshw Res 38:103-119

> Cortés E (1997) A critical review of methods of studying fish feeding based on analysis of stomach contents: application to elasmobranch fishes. Can J Fish Aquat Sci 54:726-738

Creel S, Christianson D, Liley S, Winnie JA (2007) Predation risk affects reproductive physiology and demography of elk. Science 315:960

Croxall JP, Reid K, Prince PA (1999) Diet, provisioning and productivity responses of marine predators to differences in availability of Antarctic krill. Mar Ecol Prog Ser 177: 115-131

Darnaude AM, Harmelin-Vivien ML, Salen-Picard C (2001) Food partitioning among flatfish (Pisces: Pleuronectiforms) juveniles in a Mediterranean coastal shallow sandy area. J Mar Biol Assoc UK 81:119-127

$>$ Darracott A (1977) Availability, morphometrics, feeding and breeding activity in a multi-species, demersal fish stock of the Western Indian Ocean. J Fish Biol 10:1-16

Devadoss P (1984) Nutritive values of sharks, skates and rays from Portonovo coast. Indian J Fish 31:156-161

Ebert DA, Bizzarro JJ (2007) Standardized diet compositions and trophic levels of skates (Chondrichthyes: Rajiformes: Rajoidei). Environ Biol Fishes 80:221-237

Galván DE, Sweeting CJ, Reid WDK (2010) Power of stable isotope techniques to detect size-based feeding in marine fishes. Mar Ecol Prog Ser 407:271-278

Gotelli NJ, Entsminger GL (2009) EcoSim: null models software for ecology. Version 7. Acquired Intelligence \& Kesey-Bear,
Jericho, VT. http://garyentsminger.com/ecosim/index.htm Guedes APP, Araujo FG (2008) Trophic resource partitioning among five flatfish species (Actinopterygii, Pleuronectiformes) in a tropical bay in south-eastern Brazil. J Fish Biol 72:1035-1054

Heck KL Jr, Carruthers TJB, Duarte CM, Hughes AR, Kendrick G, Orth RJ, Williams SW (2008) Trophic transfers from seagrass meadows subsidize diverse marine and terrestrial consumers. Ecosystems 11:1198-1210

Heithaus MR, Frid A, Wirsing AJ, Worm B (2008) Predicting ecological consequences of marine top predator declines. Trends Ecol Evol 23:202-210

Heithaus MR, Frid A, Vaudo JJ, Worm B, Wirsing AJ (2010) Unraveling the ecological importance of elasmobranchs. In: Carrier JC, Musick JA, Heithaus MR (eds) Sharks and their relatives II: biodiversity, adaptive physiology, and conservation. CRC Press, Boca Raton, FL, p 607-633

Hooge P, Eichenlaub W (2000) Animal movements extension to Arcview. Alaska Biological Center, US Geological Survey, Anchorage, AK

Hussey NE, Brush J, McCarthy ID, Fisk AT (2010) $\delta^{15} \mathrm{~N}$ and $\delta^{13} \mathrm{C}$ diet-tissue discrimination factors for large sharks under semi-controlled conditions. Comp Biochem Physiol A $155: 445-453$

> Hyslop EJ (1980) Stomach contents analysis - a review of methods and their application. J Fish Biol 17:411-429

> Kenyon RA, Loneragan NR, Hughes JM, Staples DJ (1997) Habitat type influences the microhabitat preference of juvenile tiger prawns (Penaeus esculentus Haswell and Penaeus semisulcatus De Haan). Estuar Coast Shelf Sci 45: 393-403

Last PR, Manjaji-Matsumoto BM, Pogonoski JJ (2008) Himantura astra sp. nov., a new whipray (Myliobatoidei: Dasyatidae) from northern Australia. In: Last PR, White WT, Pogonoski JJ (eds) Descriptions of new Australian chondrichthyans. CSIRO Marine and Atmospheric Research, Hobart, p 303-314

> Layman CA, Arrington DA, Montana CG, Post DM (2007a) Can stable isotope ratios provide for community-wide measures of trophic structure? Ecology 88:42-48

> Layman CA, Quattrochi JO, Peyer CM, Allgeier JE (2007b) Niche width collapse in a resilient top predator following ecosystem fragmentation. Ecol Lett 10:937-944

Lucena FM, Vaske T Jr, Ellis JR, O'Brien CM (2000) Seasonal variation in the diets of bluefish, Pomatomus saltatrix (Pomatomidae) and striped weakfish, Cynoscion guatucupa (Sciaenidae) in southern Brazil: implications of food partitioning. Environ Biol Fishes 57:423-434

MacNeil MA, Drouillard KG, Fisk AT (2006) Variable uptake and elimination of stable nitrogen isotopes between tissues in fish. Can J Fish Aquat Sci 63:345-353

> Marshall AD, Kyne PM, Bennett MB (2008) Comparing the diet of two sympatric urolophid elasmobranchs (Trygonoptera testacea Muller \& Henle and Urolophus kapalensis Yearsley \& Last): evidence of ontogenetic shifts and possible resource partitioning. J Fish Biol 72:883-898

> Matich P, Heithaus MR, Layman CA (2010) Contrasting patterns of individual specialization and trophic coupling in two marine apex predators. J Anim Ecol doi:10.1111/j. 1365-2656.2010.01753.x

> Moore JW, Semmens BX (2008) Incorporating uncertainty and prior information into stable isotope mixing models. Ecol Lett 11:470-480

> Myers RA, Baum JK, Shepherd TD, Powers SP, Peterson CH (2007) Cascading effects of the loss of apex predatory sharks from a coastal ocean. Science 315:1846-1850

Pace ML, Cole JJ, Carpenter SR, Kitchell JF (1999) Trophic 
cascades revealed in diverse ecosystems. Trends Ecol Evol 14:483-488

Peterson BJ, Fry B (1987) Stable isotopes in ecosystem studies. Annu Rev Ecol Syst 18:293-320

Peterson CH, Fodrie FJ, Summerson HC, Powers SP (2001) Site-specific and density-dependent extinction of prey by schooling rays: generation of a population sink in topquality habitat for bay scallops. Oecologia 129:349-356

Pinkas L, Oliphant MS, Iverson ILK (1971) Food habits of albacore, bluefin tuna and bonito in Californian waters. Calif Dept Fish Game Fish Bull 152:1-105

Platell ME, Potter IC (2001) Partitioning of food resources amongst 18 abundant benthic carnivorous fish species in marine waters on the lower west coast of Australia. J Exp Mar Biol Ecol 261:31-54

Platell ME, Potter IC, Clarke KR (1998) Resource partitioning by four species of elasmobranchs (Batoidea: Urolophidae) in coastal waters of temperate Australia. Mar Biol 131: 719-734

Quevedo M, Svanback R, Eklov P (2009) Intrapopulation niche partitioning in a generalist predator limits food web connectivity. Ecology 90:2263-2274

Ripple WJ, Beschta RL (2006) Linking a cougar decline, trophic cascade, and catastrophic regime shift in Zion National Park. Biol Conserv 133:397-408

Ritchie EG, Johnson CN (2009) Predator interactions, mesopredator release and biodiversity conservation. Ecol Lett 12:982-998

Schluessel V, Bennett M, Collin S (2010) Diet and reproduction in the white-spotted eagle ray Aetobatus narinari from Queensland, Australia and the Penghu Islands, Taiwan. Mar Freshw Res 61:1278-1289

Schoener TW (1970) Nonsynchronous spatial overlap of lizards in patchy habitats. Ecology 51:408-418

Semmens BX, Moore JW (2008) MixSIR: A bayesian stable isotope mixing model, Version 1.04. Available at www. ecologybox.org

Stead J, Bennett M (2008) The diet and feeding ecology of sympatric orectolobiform sharks: an example of resource partitioning. Joint Meeting of Ichthyologists and Herpetol-

Editorial responsibility: Yves Cherel,

Villiers-en-Bois, France ogists. Montreal, Canada 23-28 July 2008. www.asih.org/ files/abstracts_2008_part4.pdf (p 44, accessed 21 Feb 2011)

Sweeting CJ, Barry JT, Barnes C, Polunin NVC, Jennings S (2007) Effects of body size, age and environment on diettissue $\delta^{15} \mathrm{~N}$ fractionation in fishes. J Exp Mar Biol Ecol 340: $1-10$

> Terborgh J, Lopez L, Nunez P, Rao M and others (2001) Ecological meltdown in predator-free forest fragments. Science 294:1923-1926

Thrush SF, Pridmore RD, Hewitt JE, Cummings VJ (1994) The importance of predators on a sandflat: interplay between seasonal changes in prey densities and predator effects. Mar Ecol Prog Ser 107:211-222

Tinker MT, Bentall G, Estes JA (2008) Food limitation leads to behavioral diversification and dietary specialization in sea otters. Proc Natl Acad Sci USA 105:560-565

VanBlaricom GR (1982) Experimental analyses of structural regulation in a marine sand community exposed to oceanic swell. Ecol Monogr 52:283-305

Vaudo JJ, Heithaus MR (2009) Spatiotemporal variability in a sandflat elasmobranch fauna in Shark Bay, Australia. Mar Biol 156:2579-2590

Walker DI (1989) Regional studies - seagrass in Shark Bay, the foundation of an ecosystem. In: Larkum AWD, McComb AJ, Shepherd SA (eds) Biology of seagrasses. Elsevier, New York, NY, p 182-210

Wallace RK Jr. (1981) An assessment of diet overlap indexes. Trans Am Fish Soc 110:72-76

Wells FE, Rose RA, Lang S (1985) An analysis of benthic marine invertebrate communities in subtidal seagrass and sand habitats in Shark Bay, Western Australia. Rec West Aust Mus 12:47-56

White WT, Potter IC (2004) Habitat partitioning among four elasmobranch species in nearshore, shallow waters of a subtropical embayment in Western Australia. Mar Biol 145:1023-1032

> White WT, Platell ME, Potter IC (2004) Comparisons between the diets of four abundant species of elasmobranchs in a subtropical embayment: implications for resource partitioning. Mar Biol 144:439-448

Submitted: May 26, 2010; Accepted: December 9, 2010 Proofs received from author(s): February 21, 2011 